\title{
Farming autonomy: Canadian beef farmers reclaiming the grass through management-intensive grazing practices
}

\author{
Erika J. Heiberg • Karen Lykke Syse
}

Received: 13 November 2019/Accepted: 7 April 2020/Published online: 1 May 2020

(C) The Author(s) 2020

\begin{abstract}
This qualitative study asks farmers in Alberta, Canada, what are their motivations for using a practice in beef production called management-intensive grazing (MIG). By adopting this practice, these farmers engage in strategies of diversification and co-production that increase the autonomy and resilience of their farms. MIG allows farmers to defy conventional agricultural practice and engage in what can be labelled a repeasantization process, a process that contributes to the discussion about conventional farming versus agroecology.
\end{abstract}

Keywords Animal husbandry B Beef production . Biodiversity · Ecology · Management-intensive grazing · Repeasantization

\section{Introduction}

Agriculture is one of the most controversial industries in the world. The global population is growing and the need for food is too, but the strain that agricultural production puts on the environment and the imbalance between industrial production and small-scale farming put the future of these practices into question. Beef production is problematic in terms of its energy use,

E. J. Heiberg $(\bowtie) \cdot$ K. L. Syse

Centre for Development and Environment (SUM), University of Oslo, Oslo, Norway

e-mail: eheiberg@ualberta.ca emissions, and extensive land use. Alternatives within beef production have been growing slowly around the world, with producers turning toward lower impact practices and methods to raise their cattle.

Research on the motivations for transition and innovation in agriculture is extensive, putting forth various arguments for how and why farmers change their practices (Anderson and McLachlan 2012; Davidson et al. 2016; Goodman 2004; Läpple et al. 2015; Marra et al. 2003; Mundel 2007; Rogers 2010; Sutherland and Darnhofer 2012). Different events, geographies, and socio-economic and socio-cultural contexts have been examined to find examples of what drives farmers to innovate. While profitability is often considered a main driver for agricultural transitions such as the one studied here, it does not explain why this change is only made by some farmers and not all. Studies show that socioeconomic status, concern for the environment, and 'turning points' such as market or environmental crisis create situations favourable for farmer adaptation. Van der Ploeg (2008) puts forth the idea that farmer adaptations are a response to the culmination of the factors listed above.

The Alberta context

Alberta spans almost $662,000 \mathrm{~km}^{2}$ with a population of just over 4.3 million (Statistics Canada 2017b). It is the second most western province in Canada. There are over 40,600 farms in Alberta, covering more than 20 million hectares of the land. Of these farms, 12,282 raise beef cattle (Statistics Canada 2017a). These farms housed 5.2 
million cattle in 2016. Alberta has the largest average headcount per beef farm in Canada at 235 animals and is home to almost $42 \%$ of the Canadian beef population (Statistics Canada 2017a). However, less than $1.5 \%$ of the Alberta population work as farm operators today (Statistics Canada 2017a). The disappearance of family farms in this part of Canada and across North America is a social concern. In light of these trends, we ask why certain farmers in Alberta adopted managementintensive grazing (MIG) practices in raising beef cattle and show how these farmers differ from the conventional agricultural ideal and argue that through this practice, they demonstrate autonomy that increases their sustainability. Rather than maximizing production for shortterm gains in yield outputs, farmers concern themselves with the longevity of the whole farm.

\section{Method}

The main empirical sources for this study were gathered through a series of interviews with farmers across Alberta and participant observation that involved joining farmers in their fields and pastures, and 'getting our boots muddy' (Syse 2009). Further, using the snowball method proved effective in identifying participants (Taylor et al. 2015). A methodological weakness of snowballing might limit the views of the participants to one side of the discussion (Taylor et al. 2015). To help overcome these limitations, over 40 individual farms and organizations were contacted, and interviews were completed with less than half, thus maintaining a level of anonymity. Also, this allowed for multiple sources for referrals. Interviewees were narrowed down primarily by those who responded to the call for participation, as well as first-come-first-serve by geographical region, allowing for a widespread set of responses throughout the province. Seventeen farms were visited between September and October 2016.

An interview guide was used with a set of questions to guide the conversation or provide prompts if participants had trouble answering questions or describing phenomena, but the semi-structured format allowed the conversation to flow naturally and gave participants the opportunity to talk about topics and issues that were most important to them. The main questions included:

1. Can you tell me a bit about the history of your farm?

2. Can you please describe your farm?
3. Are you a full-time farmer?

4. What are some of your goals for your farm?

5. Please tell me about your management practices and how MIG fits into them.

6. Have you faced any challenges using these practices?

7. What are the major challenges facing your operation?

Interviews were transcribed using the software HyperTranscribe $^{\mathrm{TM}}$, resulting in almost 300 pages of transcript that were preliminarily coded using NVivo11 ${ }^{\mathrm{TM}}$ and then categorized into trends. These emerging categories and trends informed the choice of using the repeasantization theory, as the main themes of repeasantization - autonomy, diversification, and coproduction-were prevalent in the initial sort and analysis of the collected data. Information from fieldwork was triangulated with an in-depth literature review, media sources, and official government statistics and documents.

Participants were located across Alberta and ranged in age from 25 to 70 , with farming experience ranging from 1 to 45 years. In total, 16 men and 7 women participated in the interviews. The gender distribution is fairly representative since $30.8 \%$ of farm operators in Alberta are female (Statistics Canada 2017a) Table 1.

\section{The Alberta beef market: export and subsidization}

Canada has one of the lowest rates of agricultural subsidies and government support among developed countries. According to the Organization of Economic Cooperation and Development (OECD 2017), Canadian agricultural subsidies only accounted for 9.4\% of farm receipts in 2014-2015. In contrast, the European Union averaged at $18.9 \%$, while Norway and Switzerland were highest with over $62 \%$ of gross farm receipts accounted for by governmental agricultural support (OECD 2017).

The focus of agricultural policy in Canada is reflected in its subsidization frameworks that span the entire agriculture and agri-food system of Canada (GF2 2013). Policies concerning individual industries in Canada make for an elaborate subsidization structure. Dairy, poultry, and eggs are supply-managed. These industries are based on domestic quota systems, which allow farmers to adjust production based on consumer 
Table 1 Participants divided by gender into age groups, marital status, education, and farming experience recorded at the time of the interviews

\begin{tabular}{|c|c|c|}
\hline & Male & Female \\
\hline \multicolumn{3}{|l|}{ Age } \\
\hline 35 and under & 2 & 3 \\
\hline $36-40$ & 2 & - \\
\hline $41-45$ & 4 & - \\
\hline $46-50$ & 1 & 1 \\
\hline $51-55$ & 3 & - \\
\hline Over 55 & 4 & 3 \\
\hline \multicolumn{3}{|l|}{ Status } \\
\hline Single & - & 1 \\
\hline Married/co-habitating & - & 1 \\
\hline Married with children & 16 & 5 \\
\hline \multicolumn{3}{|l|}{ Education } \\
\hline High school & 2 & - \\
\hline Trades ticket & 4 & - \\
\hline Post-secondary & 10 & 7 \\
\hline \multicolumn{3}{|c|}{ Farming experience in years (not including childhood) } \\
\hline Under 5 & 2 & 3 \\
\hline $5-15$ & 1 & - \\
\hline $16-25$ & 5 & 1 \\
\hline $26-35$ & 4 & 3 \\
\hline Over 35 & 4 & - \\
\hline
\end{tabular}

demand and negotiate their own prices. This limits their dependence on exports and competition from imports (FSC 2011). In contrast, hogs, grain, and beef are export-dependent industries. Globalization has increased competition in these markets, as Canada now competes with several other countries that it may not have before, resulting in increased market volatility (Anderson 2010).

The graph below demonstrates the difference in income stability and profit between supply-managed and export-dependent agricultural industries in Canada in recent years: Fig. 1.

These policy structures are not without their downfalls. In 2003, Canadian borders were immediately closed to all beef exports following the discovery of bovine spongiform encephalopathy (BSE or mad cow disease), compromising the industry's reliance on exports and reluctance toward government intervention (Stephenson 2013). The graph in Fig. 1 (above, dashed line) shows a stark decrease in income for beef farmers in 2003 (correlating with the BSE crisis). Many studies on BSE in Canada account for recent changes, adaptations, and innovations among Canadian beef farmers and the beef industry in general (Anderson and McLachlan 2012; Davidson et al. 2016; McLachlan and Yestrau 2008; Mount and Smithers 2014; Stozek 2008). This was a difficult period for Canadian beef farmers, and with industrialization and neoliberal policies, both subsidization and profits of the beef industry in Canada became even more concentrated. Today, over $60 \%$ of the cattle in Canada are fattened for slaughter in Alberta, primarily in one of the 149 feedlots in the province that feed a minimum of 1000 animals each (ACFA 2017). This concentration of power and resources has implications for the industry.

Implications of industrialization and neoliberalization

Overall, the beef industry in Alberta has expanded over the past century. Multiple studies have looked at the effects and implications of land-use change for industrialization. Areas are cleared and levelled for crop production and feedlot development; water sources diverted for irrigation; and the health of soils, aquatics, and wildlife compromised by the use of technological developments including growth hormone promotants, pesticides, and chemical fertilizers (Altieri and Nicholls 2003; Bulluck et al. 2002; Hünerberg et al. 2014; Nguyen et al. 2012). Overall, the conversion of land for agricultural and industrial needs in Canada has resulted in an average loss of $2.78 \%$ of its grasslands every year (WWF 2016). While greenhouse gas (GHG) emissions per kilogramme of beef have decreased over time, the total amount of emissions from Canada's beef production increased by 28\% from 1981 to 2011 (Legesse et al. 2016). Manure is stored, transported, and deposited, resulting in both direct and indirect emissions. Grain feeding requires crop production, which uses equipment and fossil fuels for cultivating, harvesting, and transporting from field to feedlot, accounting for a significant portion of GHG emissions (Nguyen et al. 2012). The culmination of these factors brands beef as the worst food product regarding environmental impact, energy use, and emissions from production (de Vries and de Boer 2010; Nguyen et al. 2012; Steinfeld 2006). 
Fig. 1 Comparison of income for dairy, beef, and hog sectors in Canada from 1993 to 2013 (Statistics Canada in NFU, 2014)

\section{Average net market income adjusted for capital cost allowance, 1993 - 2013}

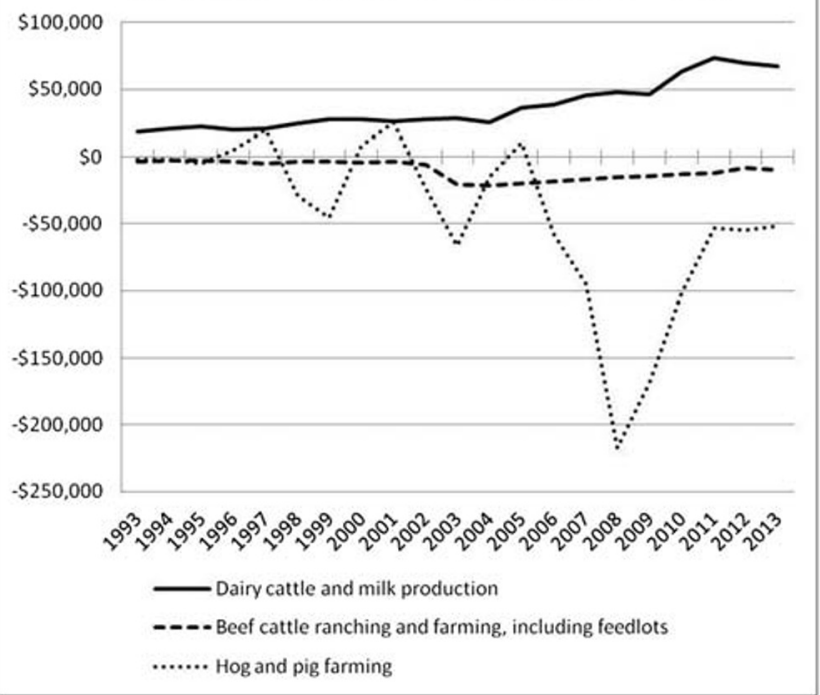

Technological developments have also created economic implications for the beef industry. External inputs such as chemical fertilizers and pesticides, rising costs of land and technology, and the demand for cheap food have placed farmers in an impossible situation: The cost of industrial food production is more than consumers are willing to pay. Van der Ploeg (2008) refers to this phenomenon as the 'squeeze on agriculture'. Farmers now face the decision to expand their farms or exit conventional agriculture in order to earn a living. The consequential decline in farmers has reduced the electoral power and political voice of the agricultural sector, thus reinforcing these neoliberal policies through acquiescence and lack of a political voice (Wiebe and Wipf 2011). The reality has been a rapid decline in small- to mid-sized family farms that have been replaced with large-scale grain operations, feedlots, agribusiness models, and corporate control (Mundel 2007).

\footnotetext{
${ }^{1}$ Metric conversions of Fig. 2b: Continuous, $0.37-0.62$ cows/ha (1 cow every $1.62-2.67 \mathrm{ha})$; slow, $1.12-1.92$ cows/ha (1 cow every 0.52 0.89 ha); planned, $3-10$ cows/ha (1 cow every $\left.1000-3000 \mathrm{~m}^{2}\right)$; MIG, 8.4-33.7/ha (1 cow every 297-1189 $\mathrm{m}^{2}$ ); Mob, 185-740+/ha (1 cow every $\left.13.5-53.9 \mathrm{~m}^{2}\right)$; adaptive, $24.5-740+$ /ha (1 cow every $13.47-$ $408.77 \mathrm{~m}^{2}$ ); stocking density assuming 5 ton per ha; and 1 animal unit, $454 \mathrm{~kg}$
}

Is the grass greener on the other side? An explanation of grazing and MIG

The simplest and most common grazing system is continuous grazing, in which animals are placed in a pasture (i.e. single paddock) for an extended period, possibly the entire grazing season (Walker 1995). As a grazing system becomes more complex, paddocks become smaller and more frequent, which increases both stock density and frequency of moves or rotations (grazing time). Figure $2 \mathrm{a}-\mathrm{c}$ are a visualization of these different grazing systems, provided by Wallace Center at Winrock International (2016) ${ }^{1}$.

Based on these diagrams, MIG is considered a modest grazing system. For some, MIG is not only a grazing system but also a form of grassland management driven by three main goals: lifestyle, financial, and environmental (Gerrish 2004). This makes MIG a wholesystems approach to grazing and grassland management and an alternative practice to conventional feedlots or continuous grazing systems for beef cattle (Schoenian 2011).

Can cows save the planet?

Alternative grazing practices with cattle have been made famous by individuals like Allan Savory. Allan Savory is best known for his programme Holistic Management, 
Fig. 2 Visual representations of different grazing systems based on grazing time (a), stock density (animals/acre) (b), and paddock size (c) (Wallace Center at Winrock International 2016)

a Grazing Systems by How Often Animals Are Being Moved

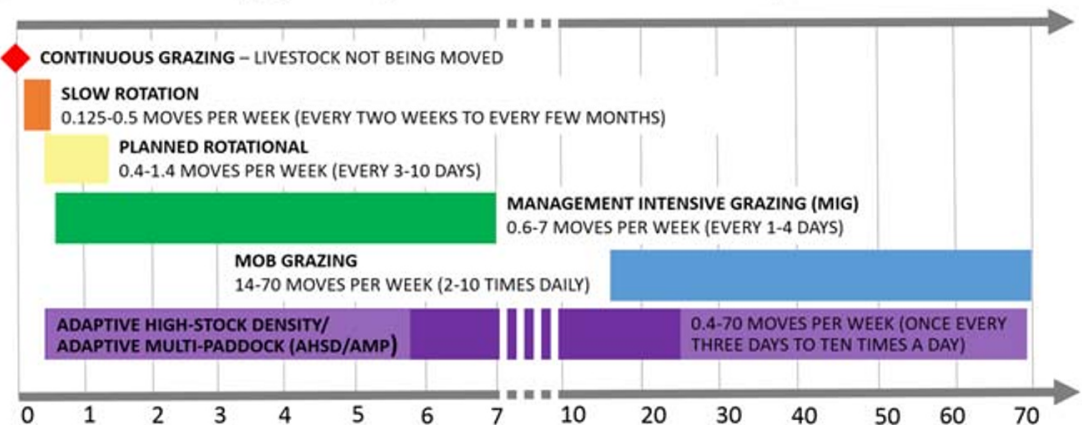

b

Grazing Systems by How Tightly Packed the Animals Are

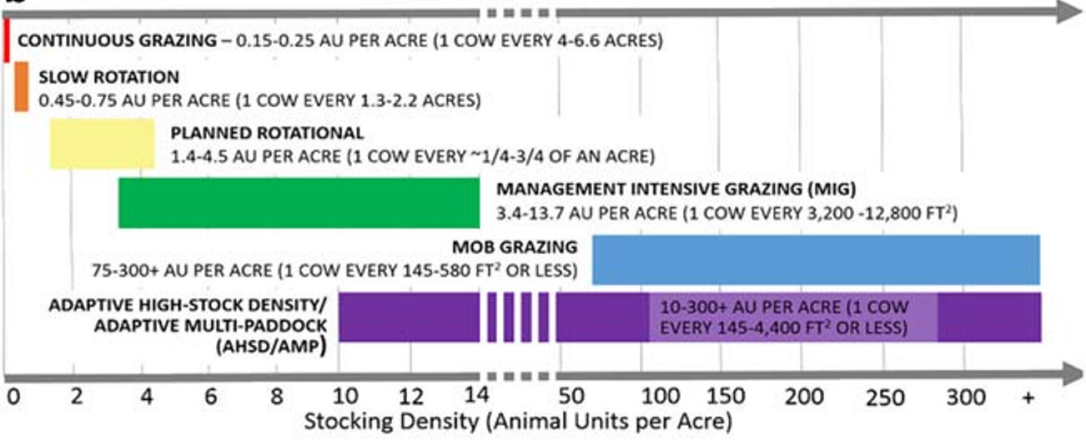

-Stocking Density calculated assuming 2 ton per acre dry matter (DM) forage production and that 1 animal unit (au) is $1000 \mathrm{lbs}$.

C

Increasing Stocking Density, Increasing Frequency of Moves

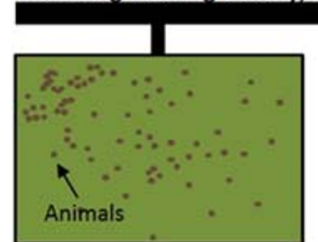

Continuous Grazing No Rotation

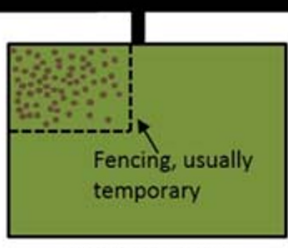

Basic Rotations

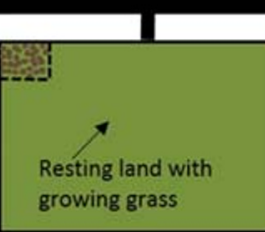

Intensive Rotational

Grazing a whole-systems planning approach that integrates social, environmental, and economic sustainability into farm planning (HMI 2017). Holistic Management is taught around the world through workshops and seminars, as well as online, and includes Holistic Planned Grazing as a way toward ecological restoration and prevention of desertification (Savory 2016). This practice is similar to MIG in that it takes into consideration the environment, economy, and social/cultural aspects of farming. However, Savory is probably one of the most controversial and polarizing voices within the discussion of land and livestock management and restoration.
Contrary to Savory and MIG practices, many scholars argue that extended grazing exacerbates the already pressing concerns of livestock production, including increased GHG emissions and water contamination. Beef production is generally considered problematic due to methane emissions from enteric fermentation in cattle and nitrate loss from manure and urine (Cuttle and Scholefield 1995; Hünerberg et al. 2014; McDowell et al. 2008; Nguyen et al. 2012; Stout et al. 2000). According to some, grassland production is even worse as it is less efficient than grain-fed production and allows for the release of more volatile substances into the environment (Nguyen et al. 2012). However, 
manure produces higher levels of methane when it is stored, so grazing systems such as Holistic Planned Grazing and MIG can reduce the emissions that result from manure management (McDowell et al. 2008; Nguyen et al. 2012). Research finds that these grazing systems can aid in carbon sequestration, assist in conserving grasslands and biodiversity, and fertilize the land with manure and urine deposits (Altieri and Nicholls 2003; Alvez et al. 2014; Bernués et al. 2011; Bocquier and González-García 2010; Cosyns et al. 2005; Garnett 2009; McLaughlin and Mineau 1995; Schwartz 2013; Teague et al. 2013). While grass-fed beef produces more methane than conventional beef, the increased carbon sequestration and conservation of grasslands and biodiversity may outweigh the negative aspects of grazing (Beauchemin et al. 2010; Cheeke and Davis 1997). In addition, beef grazing aligns most closely with the social ethics of farming and husbandry, as animals (in climates suitable for this) are kept in their natural environment and not concentrated and housed indoors, addressing concerns for animal welfare and quality of life for livestock (Cheeke and Davis 1997). Irrespective of these debates, the community of farmers using MIG practices in Alberta has grown substantially over the past decade.

Van der Ploeg's concepts of farming styles and repeasantization

Rapid industrialization and neoliberalism have revolutionized the agri-food system, but concerns for sustainability call into question whether these trends can continue given the current state of the environment, economy, and society. In answering these debates, farmers and researchers pursue diverging paths of agricultural development. This divergence speaks to several factors involved in agriculture today, which include the differing values and worldviews that individuals hold. For example, Fairweather and Campbell (2003) found two conflicting worldviews among New Zealand farmers: a systems-level approach to agriculture, which would call for a change in practice to enhance biological activity (such as MIG and Allan Savory's Holistic Management), and a technological approach, which uses a technological fix to improve existing agricultural practices (such as feedlot efficiency). To understand how these differences play out, Van der Ploeg (2008) outlined three distinct styles of farming: capitalist farming, entrepreneurial farming, and peasant farming.
Capitalist farming is the epitome of modern agriculture, also referred to as conventional or industrial agriculture. It seeks to maximize profit through expansion and intensification reliant on agricultural expertise and external inputs, such as artificial fertilizers, pesticides, genetically modified (GM) seeds, and hormonal growth implants (Van der Ploeg 2008; Nelson and Stock 2016). A defining feature of capitalist farming is the commodification of the labour force (Van der Ploeg 2014).

Entrepreneurial farming focuses primarily on extending commodification (Van der Ploeg 2010). Land is considered a commodity, as opposed to something that is living and evolving, and value is added primarily through a horizontal expansion of the land base (Nelson and Stock 2016; Van der Ploeg 2010). That is, bigger means better. Entrepreneurial farming is reliant on financing; it is a system of using money to make money but excludes labour (Van der Ploeg 2015).

Peasant farming is defined by its relatively small land base with a heavy focus on self-subsistence and sustained productivity of one's own land, as opposed to expanding outward. It relies on building capacity from within the farm as opposed to using external inputs. As such, peasant farming works to increase internal carrying capacity (Walker 1995). While the traditional peasant is considered stagnant, fixed in routines, and focused on subsistence, repeasantization involves a farmer who is dynamic, adjusting to the natural, political, and social forces that affect one's livelihood and farming practices (Van der Ploeg 2008).

Van der Ploeg's conceptualization of farming styles can be further understood in relation to the Danish ethnologist Thomas Højrup's structural life-mode analysis (Højrup 2003). This analysis is based on the diverse cultural relations that exist within a society, in which Højrup (2003) assumes that these differences are based on people's specific life-mode, which forms the basis for individual values, ideologies, and practices. The wageearner life-mode, in which a person's work is a means to an end (i.e. free time and pleasure), is most aligned with the capitalist farming style, as most people are employed on a farm and earn a wage to use in their free time (Højrup 2003). In contrast, the self-employed life-mode is most aligned with the peasant style of farming, in which the person owns their enterprise and means of production. However, as farmers adjust to the forces affecting their livelihood, they work to secure their self-employment and do what they can to maintain their 
farm, thus also fitting Van der Ploeg's concept of repeasantization (Højrup 2003).

Repeasantization was popularized by Van der Ploeg (2008) to label the re-emergence of peasant farming. It is defined by a search for greater autonomy from political and economic forces using two categories of practices: co-production, in which nature and humans are understood as interacting to create mutual and dynamic transformations, and diversification of income activities, both on and off the farm (Van der Ploeg 2014). A subset of diversification, multi-functionality, is the development of products and services (agricultural and non-agricultural) on a farm that goes beyond the production of raw agricultural materials but use the same resource base (Van der Ploeg 2015). However, Van der Ploeg and Roep (2003) argue that multi-functionality includes 'broadening' activities that are non-agricultural, such as landscape or ecosystem services management; 'deepening' activities that are agricultural and differentiate already existing products to increase value, such as organic production, or milk processing facilities on a dairy farm; and 'regrounding' activities, in which the farm is supported by off-farm income (new set of resources), and/or low-input agriculture, in which MIG is a common practice.

Repeasantization has emerged as a concept in developed countries, with research focused on the growth of organic agriculture in the USA, smallholder dairy farms in the Netherlands, and multi-functionality in the UK (Marsden 1998; Nelson and Stock 2016; Van der Ploeg 2003). The so-called squeeze on agriculture has resulted in farmers moving between the three styles of farmingcapitalist, entrepreneurial, and peasant, but of most interest in this study is the process of repeasantization. As MIG focuses on building land productivity, integration of animals with the landscape, and low input production (Teague et al. 2013), MIG works to increase the internal carrying capacity of a farm, thus building farmer's autonomy, fitting within the peasant style of farming. The farmers in this study can all be placed on a spectrum of repeasantization (Nelson and Stock 2016; Van der Ploeg 2000).

\section{Results and discussion}

The complexities of diversification

To demonstrate the benefits, challenges, and complexities of MIG diversification, we will focus on two examples from the study: first, mixed farming. Conventional agriculture pushes for the specialization of monocultures, horizontal expansion, and high commodity production, but a diversified farm focuses on polycultures and vertical integration of commodity and non-commodity farm activities. As a result, farmers can produce more with less, at least regarding natural resources such as land and livestock numbers. The farmer Larry emphasized how diversifying his farming system expanded his production:

... [W]e realized that you need to have some diversity on the farm and then, of course, we're focused on perennial forages so then we always look at different ways of marketing the crops and whatnot.... The leafcutter bees became a tool.... So, then we focus on pollination and bee reproduction, and of course with seed production then you get seed pollinated so then you've got seed that you can market and harvest and sell.... And then after the seed is harvested, you still have the straw; and the grass and stuff, because it's a mixed, diverse species, you still have that [as] feed for livestock, and of course, then ruminants come into play...[And] the dairy cattle then, we recognize the value of having a milk cow on the farm for good food supply, and we get so many things out of it like butter and cheese.... So it's another means, another form of product conversion and a tool that we can use to harvest the grass, but then it adds a little bit more diversity to the farm (Larry).

Larry took advantage of the symbiotic relationships among diverse species. This decreased the need for artificial fertilizers by improving nutrient cycling, as nutrients were not moved off of a resource base but incorporated back into it, creating a closed cycle (Sayre et al. 2012). Thus, he expanded his autonomy by decreasing reliance on outside inputs and increased his capacity without having to expand his land base. According to Van der Ploeg (2014), this characterizes a contrast to the capitalist style farming. While capitalist farming focuses on an economy of scale - producing more of one variety over a larger scale to increase yield-diversification focuses on an economy of scope, where each crop might have lower yield than if it was produced in a monoculture, but together the number of calories produced by the mix of enterprises is greater, thus increasing the productivity of the land (Van der Ploeg 2014).

Our second example pivots around waged jobs. In Alberta, approximately $47 \%$ of farmers reported having 
an off-farm job in 2015 (Statistics Canada 2017a). Thomas Højrup (2003) suggests that self-employed commodity producers form a life-mode in which their social and cultural relations are structured around their self-employed enterprise. This life-mode, including farmers, considers self-employment as the freedom to work, as opposed to the obligation to work. Thus, the self-employed are geared toward the great pursuit of maintaining the production of their own enterprises and utilize waged work as a means to support or supplement that enterprise, as it helps them achieve their goals of independence through self-employment (Højrup 2003). Off-farm, waged work helps to sustain farms and farming communities concomitantly.

In this study, the main reason farmers held an offfarm job was to build capital to invest in their farms. Bessant (2000) contends that this 'aspiring type' of farmer is typical of small to medium-sized farms. Working to build capital to further their self-owned enterprise is part of their great pursuit - the freedom of self-employment. While diversifying a farm may reduce economic hardships, it has also shown to negatively affect farm life and agricultural production. Multiple studies have found that diversification takes time and attention away from the farm, reduces the resources devoted to farm work (e.g. labour), and can create latency in farm management (Anderson and McLachlan 2012; Knowler and Bradshaw 2007; Läpple et al. 2015; McLachlan and Yestrau 2008). Läpple et al. (2015) found that innovation dropped as farmers took off-farm jobs.

While mixed farming has been shown to improve productivity, it also has downfalls. Farmers like Greg, who has multiple on- and off-farm enterprises, saw the possible adverse effects. He said: "I think you're better to have some multiple industries, but just focus on maybe a few and just do a lot better job at those things (Greg)". Greg recognizes the tipping point at which a farmer is most effective or overworked. This exemplifies how a willingness to innovate may also be affected by the availability of labour on the farm. Some farmers felt they were playing an endless game of catch-up: as diversification could also result in 'the squeeze',

There's just too much of [this] going on. We keep crutching the farm with this other occupation and it's absolute insanity - like no other business. I don't work as a plumber to support my carpentry business. You know, that just doesn’t exist (Greg).

The continuous need for off-farm work flustered Greg. Based on Højrup's (2003) life-mode analysis, this frustration can be understood as an obstacle to or failure of the self-employed farmer's main pursuit-independence through free work. The economic and social pressures in today's conventional agriculture emerged as a strong motivation for the farmers in this study to engage in MIG practices. In contrast to the diversification strategies explored above-mixed farming and off-farm waged jobs-most of these farmers have taken up activities that strengthen or deepen their primary enterprise - namely, beef production - and utilize MIG to do so.

Whereas only some of the farmers interviewed had mixed farms and even fewer held off-farm waged jobs, all of them were involved in so-called deepening activities that increase the value of an already existing product (e.g. organic production, speciality products, processing of raw materials, direct marketing, etc.). Some farmers earned income by providing resources related to their farming practices, and some diversified their product lines by taking the cattle and forages they produce and turning them into something more, either extending their product line or deepening their value.

\section{Value-adding among farmers using $M I G$}

Value-adding techniques and practices were the most common forms of diversification carried out by the farmers in this study and entail taking a raw commodity, such as beef, and changing it in a way that differentiates it from the original. This includes grass-fed beef, selective breeding, organic and natural (no hormone, no antibiotic) production, and product or farm accreditation. According to Van der Ploeg (2009), value-adding on the farm distinguishes repeasantization from entrepreneurial or capitalist farming styles and relates back to the traditional agricultural practices. Stinner, Glick, and Stinner (1992) contrast agriculture from before and after the Industrial Revolution, stating that value-added products used to be common for farmers to increase cash flow and build capital. The dawn of industrialization brought modern, conventional 
agriculture, focused on expanding production that resulted in bigger farms that ignored, or even diminished, value-added processing.

Approximately half of the farms that were part of this study market grass-finished beef. ${ }^{2}$ With overall lower fat and higher concentrations of essential nutrients than conventional grain-fed beef and less embedded pollution than feedlot practices (Clancy 2006), grass-based production is considered an added value. But farmers require markets to sell these products and an animal breed fit for grass-finishing. As a result, farmers can be very selective in the cattle they keep on their farms and attentive to how well animals perform.

Natural and organic beef have grown in popularity, with markets for these products exploding in the last decade. Both types of production follow certain guidelines and need to be certified to earn their titles. These farmers produce more than 'just beef'. While producers might invest time, money, and energy into value-added production, 'it is all for naught if the product is not marketed in such a way as to capture that additional value' (Smith 2007). For many of these farmers, this comes with building social licence:

That's something we've got to be more aware of as well. Knowing who our customers are and what our customers expect out of us. It used to be, 'farmers, oh they're good people, they do everything right.' But that's going by the wayside now. People are more seeing that 'oh, you know, animal welfare is part of his priority;' like on our gate post down there. We've got the Environmental Farm Plan and the Verified Beef program and the McDonald's as well. So, we're proactive at doing that...because [we] have to watch and listen to what the consumers are asking (Frank).

A response to consumer demands came in 2014 when McDonald's launched its Sustainable Beef Pilot in Canada as part of the Global Roundtable for Sustainable Beef. Their five principles of sustainable beef production include natural resources, people and the community, animal health and welfare, food, and efficiency and innovation (McDonald's 2016). This pilot programme utilized the existing Environmental Farm Plan and

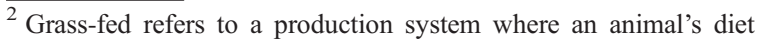
consists of grass and forage but may be supplemented with grain (primarily close to slaughter). Grass-finished means an animal is fattened on only grass and forages from birth to slaughter (Clancy 2006).
}

Verified Beef Production accreditations to operationalize and measure their principles of sustainable production. Programmes like this are designed to address issues of environmental risk and management, animal care and biosecurity, and on-farm food safety practices (EFP 2016; VBP+ 2017).

While demand for grass-fed, natural, and organic beef is growing, so is the number of farmers and businesses producing them. By adding certifications, farmers can differentiate themselves from the crowd as responsible landowners and caretakers, attentive to consumer values, not just the demand. However, with increased public attention to the environment and concern for where food comes from, these programmes also give farmers the tools to keep detailed records. If they ever need to demonstrate due diligence, they can.

\section{Creating space: off the farm, but of the farm}

Some farmers generated extra income by communicating MIG knowledge to others. Some did this hands-on, i.e. by working as farm equipment distributors, while others engaged in consultancy or workshop facilitation on grazing and cropping, or as Holistic Management Certified Educators. ${ }^{3}$ This involves supplying knowledge of both hard and soft skills that are not commonly used in conventional agricultural practices.

Unlike mixed farming and off-farm waged jobs, distributing and constructing supplies, consulting on agricultural tools and strategies, and facilitating learning opportunities provide farmers control over their own schedule, rather than having it overrun with different activities. Such deepening activities allow farmers to maintain personal autonomy and aid in maintaining farm autonomy by providing cost-saving measures and access to knowledge while keeping the farm at the centre of both on- and off-farm activities. It also allows farmers to share their own knowledge and skills with other local farmers. Kloppenburg (1991) argues that farmers, particularly unconventional ones, rely heavily on local knowledge because it is empirically adapted to the local context. This has led to greater recognition and interest in the process of 'farmer first' knowledge production and dissemination, as opposed to just a

\footnotetext{
${ }_{3}^{3}$ Holistic Management Certified Educators are trained to teach and consult farmers in using Holistic Management on their farms. Certification is managed and given by Holistic Management International (2017).
} 
technological transfer from laboratories to the field. Kloppenburg shows that farmer-driven knowledge dissemination has thrived despite decreased governmental support.

All farmers in this study felt that diversification in some way or another was essential, demonstrating a resistance to the conventional model that thrives on specialization. While common diversification practices such as mixed farming and working a second, waged job can help create stability and spread risk for farmers; these practices also have a tendency to spread a person thin, limiting their ability to make changes or engage in learning opportunities, or to spend time with friends and family. In contrast, activities that deepen their farm production help farmers gain autonomy by adding value, increasing their market opportunities, social licence, engagement with other farmers, and innovation in farming practices. Understanding the value of a diversified farm requires a different view of agriculture - one that values both commodity and non-commodity production. MIG motivated these farmers to share their skills and knowledge: a coproduction. Accordingly, the farmers' motivations and use of MIG are co-produced, but their practices also helped the farmers develop a story; they depicted nature as a partner with which they could both collaborate and have a productive dialogue.

\section{Co-production for carrying capacity}

All farmers interviewed for this study said that increased production was a primary motivation for using MIG. Unlike industrial agriculture, this benefit came without the use of machinery or other external inputs. From an industrial economic perspective, the carrying capacity of an ecosystem is based on what can be extracted or consumed without overwhelming or polluting the system (Srivastava et al. 1999). As a result, natural habitats are replaced to accommodate the production of cash crops and livestock facilities, which compromises the carrying capacity of the native ecology of a place, and ignore the capacity of areas considered unsuitable for industrial agricultural production (Berry 2015a; Cote and Nightingale 2012; Kofinas 2009; Srivastava et al. 1999). This definition fits within the capitalist farming style.

In contrast, others consider carrying capacity to include the entire ecosystem, such as McLaughlin and Mineau (1995), who consider carrying capacity to include both commodity production and its effect on wild biodiversity, such as bird populations and their habitats. Walker (1995), on the other hand, defines carrying capacity in terms specific to grazing management, drawing on a definition from the Society for Rangeland Management. In this regard, carrying capacity is the greatest number of animals that an ecosystem can support while 'maintaining or improving vegetation or related resources' (in Walker 1995, 352). Walker approaches carrying capacity from a completely different direction, as he asks how to improve it, and frames livestock as a tool to generate this improvement. Accordingly, it opposes the industrial mode of agriculture by not just taking from but giving back to the land. MIG increases the carrying capacity; thus, it supports the findings from interviews with farmers (Anderson and McLachlan 2012; Teague et al. 2013; Walker 1995). Liam, who has been farming for over 30 years, believes that with MIG, he not only maintains or improves his land but also increases its carrying capacity, which demonstrates the co-production implicit in Walker's definition.

Overall, MIG helps to increase carrying capacity by improving resources, better utilizing the resources that are available, and creating a more compact farm. This is because farmers can produce more livestock without having to increase their land base, increasing their profitability.

So, we started out where I thought it took about six acres to run a cow for a year, and I think we're somewhere at five and a half now. And that's as good of all-encompassing measures [as] I can come up with for progress. That means our pastures are more productive (Walter).

\section{Continual vs. continuous progress}

A continual process is one that starts and stops, and this sequence repeats indefinitely (Oxford English Dictionary, s.v. 'continual'). Conventional agriculture is designed to be continual, where farmers use up the resources available and then replace them with artificial inputs. While technological developments such as pesticide-resistant crop varieties may improve yields, the system ultimately becomes exhausted, as crops require the same nutrients, while the means to replace the nutrients is not part of the system. Natural means of 
nutrient replenishment are removed when habitats are altered to accommodate monoculture production. These conditions result in problems such as the superweed effect (Gurian-Sherman and Mellon 2013); the eventual need to start again, by ploughing up a field or pasture; and a constant reboot of the system with artificial inputs such as chemical fertilizers and pesticides. This demonstrates the continual progress that has to stop and start again every so often. Industrial forms of livestock production-primarily confined animal feeding operations (CAFOs) - have created a similar continual progression. With the increased use of antibiotics, CAFOs have built up antibiotic resistance in animals, as well as influenced the development of antibiotic-restistant bacteria strains (Cooprider et al. 2011; FAO 2009; NFU 2008).

In contrast, agroecological practices like MIG are designed to be continuous, meaning that they help create systems of uninterrupted progress (Oxford English Dictionary, s.v. 'continuous') (Fig. 3). When appropriately used, carrying capacity improves over time, resources are made stronger, and the production system becomes more efficient without needing a reboot. Farmers were asked what changes they have noticed since starting with MIG. Michael's response reflected this contrast in progress between conventional practices and MIG:

I'm noticing pastures get stronger rather than weaker. (...) I've watched water run off neighbours' fields and nothing's moved from ours. (...) I've seen neighbours' pastures that get a green tinge to them, but there's no production out there even though the cows are back out. I've had

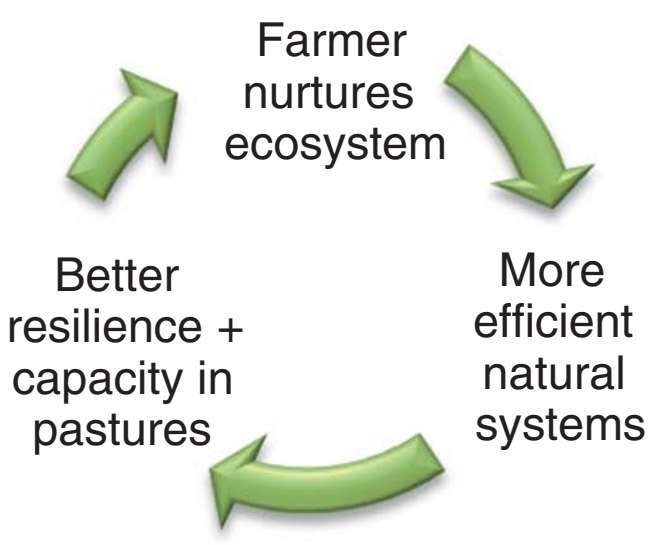

Fig. 3 Co-production can be viewed as a positive feedback loop in MIG that increases carrying capacity and natural resilience phenomenal grass production compared to other pastures in very close proximity... (Michael).

Farmers made claims of increased production but were specific about limiting their understanding to the quality of their own soil and land, their own topography, and their own climate conditions. Throughout the interview process, farmers shared sentiments of place-based practices, which demonstrated that using MIG is not generic, but requires craftsmanship.

\section{Input use}

An input is anything added to the land or used by people to produce an agricultural product. The external inputs that farmers decreased their use fell into two categories: heavy equipment or machinery and artificial chemical inputs. For instance, when asked what kind of equipment he uses on a daily basis, Frank curved his fingers to form a ' 0 ', saying,

We don't turn a wheel to feed cattle; it's totally year-round grazing... We've got a 2009 John Deere out here; it's only got 300 hours on it, bought brand new. So, we just don't use them. And that's the only way you can make money in the cattle business is cut that bottom [line], because we're an industry of price takers, not price makers, but we can push that bottom margin (Frank).

In an industry that has started to pride itself in 'bigger means better', this preference demonstrates the counterhegemonic nature of using MIG.

Fertilizing Research shows that there are multiple benefits to using manure as opposed to chemical fertilizers. Manure has been shown to increase biological activity and organic matter in the soil (Bernués et al. 2011; Garnett 2009; McLaughlin and Mineau 1995), assist with weed and pest control (Gurian-Sherman and Mellon 2013), and help to create a closed cycle for nutrient recycling, which slows or even reverses soil degradation and exhaustion (Alvez et al. 2014; Amekawa 2011; Bernués et al. 2011; Bocquier and González-García 2010; McLaughlin and Mineau 1995). By managing the cattle in smaller cells, manure and urine are more evenly distributed across a pasture 
than in continuous grazing, as animals are confined to smaller areas and moved frequently. This limits their ability to spend time around their 'favourite' spots and can help ensure that an entire pasture is more or less evenly fertilized with a calculated movement of the herd (White et al. 2001).

Beef production is considered problematic due to enteric methane emissions and nitrate leaching from manure and urine (Hünerberg et al. 2014; Nguyen et al. 2012; Stout et al. 2000). However, manure is more problematic when it must be stored, transported, and deposited (McDowell et al. 2008; Nguyen et al. 2012), and the added benefits of increased soil carbon storage and absorption of nitrates into the soil that occur in grazing systems may help to counterbalance these adverse effects (Beauchemin et al. 2010).

Harvesting Saliva contains a variety of nutrients, salts, and urea that work to help cattle digest cellulose and other fibrous materials, a unique characteristic of ruminants (Bocquier and González-García 2010; Gullap et al. 2011; Lamy and Mau 2012; Nardone et al. 2010). Research shows that saliva from ruminants may also stimulate plant growth that could result in increased density and biomass, depending on the grass species and soil type (Gullap et al. 2011; Lamy and Mau 2012). Consequently, this suggests a symbiotic coproduction; as cattle graze, they stimulate the plants, which grow back with more density, thus providing even greater volumes of feed for grazing animals.

By utilizing MIG practices, these farmers coproduce with nature to create a production system that uses limited external inputs. Profitability was the most apparent reason for decreasing input use. Artificial inputs have been revolutionary in agriculture and, on the surface, can seem positively powerful. However, all of this 'power' costs farmers money and autonomy. This loss of autonomy was demonstrated with the development of hybrid corn, as farmers gained better yields but lost control and power over their harvest and seed base (Moore 2010). MIG provides various farmers, whether organic or commercial, an opportunity to gain autonomy from this capitalization of agriculture. Both of these types of farmers use their local knowledge and expertise to decrease their need for off-farm income and increase their autonomy in making financial/economic decisions (Van der Ploeg 2014). Despite different types of farms, farmers utilize their local knowledge to create profitable farms in different ways.

Knowledge autonomy

According to Stock and Forney (2014), knowledge autonomy is central to the farmer identity and not only considered a value in farming but a tool farmers use to secure their place in the social milieu of agriculture today.

As mentioned earlier, the inputs used in conventional agriculture have reduced the power and autonomy of farmers because farmers lack control over these resources. The use of these tools has ensured the dependence of both farmer and nature on their use. These implications may prevent farmers from transitioning to practices such as MIG, as there is inevitably a transition period required. Farm productivity in terms of yield output and overall production is a central concern for farmers considering a transition to organics. Research shows that this transition typically takes 3 to 5 years before production resumes or increases without the use of these external inputs (Bulluck et al. 2002; Cranfield et al. 2010). In light of the squeeze on agriculture, this might discourage farmers from making such a transition, but the farmer Larry expressed the urgency of the situation:

We're losing as it is; we're losing farmers, we're losing knowledge, we're losing markets; we're losing all kinds of things. And have become totally reliant on inputs from some foreign corporate entities with chemicals, and fertilizers, and fuels, and machinery; and so our country is becoming non-productive, non-secure, non-sustainable (Larry).

Larry summarized the implications of conventional agriculture that all the farmers interviewed touched on, although not all were as explicit in their description. He expressed the need for local knowledge and understanding to overcome the squeeze on agriculture and the reliance on external inputs.

When farmers use co-production instead of onesize-fits-all solutions, they utilize their local knowledge of place and nature, demonstrating 
autonomy of knowledge that is not only autonomous from the technological developments but also from conventional production. Instead of maximizing production for short-term gains in yield outputs, MIG farmers concern themselves with the longevity of the whole farm.

\section{Conclusion}

Because farmers find themselves in precarious situations due to the price-cost squeeze, dwindling rural populations, volatile markets, and unpredictable climates, they draw on different diversification strategies to provide stability and resilience on their farms. The continuous reliance on off-farm income could create a sense of frustration and disgruntlement as farmers feel they are always in a state of crisis. When farmers work to produce value-added products such as grass-fed, natural, or organic beef, MIG provides them with the tools and strategies to optimize the production of both the cattle and land and thus increase profitability. In turn, their success in these practices opens doors for them to share and network with others. As a result, these farmers have built a strong community around the use of MIG and forages. These practices that are rooted in farming and enhancing farm production help farmers feel independent, successful, and resilient in their practices.

Using co-production instead of inputs and relying on local knowledge to build and utilize their resources, farmers create a more profitable and sustainable operation. This included more than just production, as it also involved a nurturing of nature, increased diversity, and community building. According to Van der Ploeg (2000), this change in perspective is 're-grounding farming on ecological capital' (p. 11), and while the farmers in this study vary in how much they distance themselves from conventional agriculture, they are all concerned with what their farming practice is grounded in.

Our findings show how the various layers of the farmers' narratives and practices build the stories behind their value-added products and explain their encompassing understanding of agriculture. They start with the soil, which builds the base of their livelihood. Without focusing on the soil, they could not sustain their farms. As farmers diversify their crops and livestock and decrease their input use, they demonstrate concern for the farm. Farmers can survive on conventional practices for a while, but phenomena like the squeeze on agriculture and the superweed effect show that these are not long-term solutions for farming. Instead, these farmers have moved away from conventional practices, demonstrating concern for the sustainability of their farms.

Thus, the farmers increase their capacity and integrate their enterprises. By expanding upward rather than outward, they produce more with less, opening space for more farmers to come in, for more neighbours and greater community. By having a holistic understanding of agriculture, these farmers are able to create an encompassing and cyclical practice, in which MIG is at the centre. They experience gains financially, environmentally, and socially. They have created a lifestyle and livelihood with which they are satisfied. While this study focused on a small collection of the farmers practicing MIG in Alberta, there is no doubt more to learn from studying similar practices in other settings and at different scales.

Funding Information Open Access funding provided by University of Oslo (incl Oslo University Hospital).

Open Access This article is licensed under a Creative Commons Attribution 4.0 International License, which permits use, sharing, adaptation, distribution and reproduction in any medium or format, as long as you give appropriate credit to the original author(s) and the source, provide a link to the Creative Commons licence, and indicate if changes were made. The images or other third party material in this article are included in the article's Creative Commons licence, unless indicated otherwise in a credit line to the material. If material is not included in the article's Creative Commons licence and your intended use is not permitted by statutory regulation or exceeds the permitted use, you will need to obtain permission directly from the copyright holder. To view a copy of this licence, visit http://creativecommons.org/licenses/by/4.0/.

\section{References}

Alberta Cattle Feeders' Association (ACFA) (2017) Facts and stats. http://www.cattlefeeders.ca/industry-overview/albertacattle-feeding-facts-and-stats/.

Alberta Environmental Farm Plan (EFP) (2016) Welcome to the Alberta environmental farm plan. http://www.albertaefp. com.

Altieri M, Nicholls C (2003) Soil fertility management and insect pests: harmonizing soil and plant health in agroecosystems. Soil Tillage Res 72(2):203-211. https://doi.org/10.1016 /S0167-1987(03)00089-8

Alvez J, Schmitt A, Farley J, Erickson J, Méndez V (2014) Transition from semi-confinement to pasture-based dairy in Brazil: farmers' view of economic and environmental performances. Agroecol Sust Food Syst 38(9):995-1014. https://doi.org/10.1080/21683565.2013.859222 
Amekawa Y (2011) Agroecology and sustainable livelihoods: towards an integrated approach to rural development. J Sustain Agric 35(2):118-162. https://doi.org/10.1080 $/ 10440046.2011 .539124$

Anderson C, McLachlan S (2012) Exiting, enduring and innovating: farm household adaptation to global zoonotic disease. Glob Environ Chang 22(1):82-93. https://doi.org/10.1016/j. gloenvcha.2011.11.008

Anderson K (2010) Globalization's effects on world agricultural trade, 1960-2050. Philos Trans R Soc B 365(1554):30073021

Beauchemin K, Janzen H, Little S, McAllister T, McGinn S (2010) Life cycle assessment of greenhouse gas emissions from beef production in western Canada: a case study. Agric Syst 103(6):371-379. https://doi.org/10.1016/j.agsy.2010.03.008

Bernués A, Olaizola A, Villalba D, Casasús I (2011) Sustainability of pasture-based livestock farming systems in the European Mediterranean context: synergies and trade-offs. Livest Sci Spec Issue 139(12):44-57. https://doi.org/10.1016/j. livsci.2011.03.018

Berry W (2015a) Our only world: ten essays. Counterpoint, Berkeley

Bessant K (2000) Part-time farming situations among Manitoba farm operators: a typological approach. Can J Agric Econ 48(3):259-277. https://doi.org/10.1111/j.1744-7976.2000. tb00279.x

Bocquier F, González-García E (2010) Sustainability of ruminant agriculture in the new context: feeding strategies and features of animal adaptability into the necessary holistic approach. Animal 4(7):1258-1273. https://doi.org/10.1017 /S1751731110001023

Bulluck L, Brosius M, Evanylo G, Ristaino J (2002) Organic and synthetic fertility amendments influence soil microbial, physical and chemical properties on organic and conventional farms. Appl Soil Ecol 19(2):147-160. https://doi. org/10.1016/S0929-1393(01)00187-1

Cheeke P, Davis S (1997) Possible impacts of industrialization and globalization of animal agriculture on cattle ranching in the American west. (Can environmentalists save the ranch?). Rangelands Arch 19(2):4-5

Clancy K (2006) Greener pastures: how grass-fed beef and milk contribute to healthy eating. Union of Concerned Scientists, Cambridge

Cooprider K, Mitloehner F, Famula T, Kebreab E, Zhao Y, Van Eenennaam A (2011) Feedlot efficiency implications on greenhouse gas emissions and sustainability. J Anim Sci 89(8):2643-2656

Cosyns E, Claerbout S, Lamoot I, Hoffmann M (2005) Endozoochorous seed dispersal by cattle and horse in a spatially heterogeneous landscape. Plant Ecol 178(2):149162. https://doi.org/10.1007/s11258-004-2846-3

Cote M, Nightingale A (2012) Resilience thinking meets social theory situating social change in socio-ecological systems (SES) research. Prog Hum Geogr 36(4):475-489

Cranfield J, Henson S, Holliday J (2010) The motives, benefits, and problems of conversion to organic production. Agric Hum Values 27(3):291-306. https://doi.org/10.1007 /s10460-009-9222-9

Cuttle S, Scholefield D (1995) Management options to limit nitrate leaching from grassland. J Contam Hydrol 20(3):299-312. https://doi.org/10.1016/0169-7722(95)00075-5
Davidson D, Jones K, Parkins J (2016) Food safety risks, disruptive events and alternative beef production: a case study of agricultural transition in Alberta. Agric Hum Values 33(2): 359-371. https://doi.org/10.1007/s10460-015-9609-8

de Vries M, de Boer I (2010) Comparing environmental impacts for livestock products: a review of life cycle assessments. Livest Sci 128(1?3):1-11. https://doi.org/10.1016/j. livsci.2009.11.007

Fairweather J, Campbell H (2003) Environmental beliefs and farm practices of New Zealand farmers. Agric Hum Values 20(3): $287-300$

Food and Agriculture Organization of the United Nations (FAO) (2009) The state of food and agriculture: Livestock in the Balance. FAO, Rome

Food Secure Canada (FSC) (2011) Agriculture, infrastructure and livelihoods. Discussion papers on the People's food policy, Montreal

Garnett T (2009) Livestock-related greenhouse gas emissions: impacts and options for policy makers. Environ Sci Pol Spec Issue 12(4):491-503. https://doi.org/10.1016/j. envsci.2009.01.006

Gerrish J (2004) Management-intensive grazing, the grassroots of grass farming. Green Park Press, Ridgeland

Goodman D (2004) Rural Europe redux? Reflections on alternative agro-food networks and paradigm change. Sociol Rural 44(1): 3-16. https://doi.org/10.1111/j.1467-9523.2004.00258.x

Growing Forward 2 (GF2) (2013) Programs at a glance http://www. growingforward.alberta.ca/ProgramGlance/index. htm? contentId=A GUCMINT-507766\&useSecondary=true. Accessed July 28, 2017

Gullap M, Ibrahim Erkovan H, Koc A (2011) The effect of bovine saliva on growth attributes and forage quality of two contrasting cool season perennial grasses grown in three soils of different fertility. Rangeland J 33(3):307-313. https://doi. org/10.1071/RJ10063

Gurian-Sherman D, Mellon M (2013) The rise of Superweeds and what to do about it. Union of Concerned Scientists, Cambridge

Holistic Management International (HMI). 2017. Holistic Management International. https://holisticmanagement.org. Accessed July 5, 2017

Hünerberg M, Little S, Beauchemin K, McGinn S, O'Connor D, Okine E, Harstad O, Kröbel R, McAllister T (2014) Feeding high concentrations of corn dried distillers' grains decreases methane, but increases nitrous oxide emissions from beef cattle production. Agric Syst 127:19-27

Højrup T (2003) State, culture and life-modes: the foundations of life-mode analysis. Ashgate, Aldershot

Kloppenburg J (1991) Social theory and the de/reconstruction of agricultural science: local knowledge for an alternative agriculture. Rural Sociol 56(4):519-548. https://doi.org/10.1111 /j.1549-0831.1991.tb00445.x

Knowler D, Bradshaw B (2007) Farmers' adoption of conservation agriculture: a review and synthesis of recent research. Food Policy 32(1):25-48. https://doi.org/10.1016/j. foodpol.2006.01.003

Kofinas G (2009) Adaptive co-management in social-ecological governance. In: Chapin FS III, Kofinas GP, Folke C, Chapin MC (eds) Principles of ecosystem stewardship: resiliencebased natural resource management in a changing world. Springer Science \& Business Media, New York, pp 77-102 
Lamy E, Mau M (2012) Saliva proteomics as an emerging, noninvasive tool to study livestock physiology, nutrition and diseases. J Proteomics 75(14):4251-4258. https://doi. org/10.1016/j.jprot.2012.05.007

Legesse G, Beauchemin K, Ominski K, McGeough E, Kroebel R, MacDonald D, Little S, McAllister T (2016) Greenhouse gas emissions of Canadian beef production in 1981 as compared with 2011. Anim Prod Sci 56(3):153. https://doi.org/10.1071 /an15386

Läpple D, Renwick A, Thorne F (2015) Measuring and understanding the drivers of agricultural innovation: evidence from Ireland. Food Policy 51:1-8. https://doi.org/10.1016/j. foodpol.2014.11.003

Marra M, Pannell D, Ghadim A (2003) The economics of risk, uncertainty and learning in the adoption of new agricultural technologies: where are we on the learning curve? Agric Syst 75(2-3):215-234. https://doi.org/10.1016/S0308-521X(02 )00066-5

Marsden T (1998) Agriculture beyond the treadmill? Issues for policy, theory and research practice. Prog Hum Geogr 22(2): 265-275. https://doi.org/10.1191/030913298669229669

McDonald's (2016) McDonald's sustainable beef pilot: final report, vol 1. McDonald's, p 2016

McDowell R, Dou Z, Toth J, Cade-Menun B, Kleinman P, Soder K, Saporito L (2008) A comparison of phosphorus speciation and potential bioavailability in feed and feces of different dairy herds using $31 \mathrm{P}$ nuclear magnetic resonance spectroscopy. J Environ Qual 37(3):741-752. https://doi.org/10.2134 /jeq2007.0086

McLachlan S, Yestrau M (2008) From the ground up: holistic management and grassroots rural adaptation to bovine spongiform encephalopathy across western Canada. Mitig Adapt Strateg Glob Chang 14(4):299-316. https://doi. org/10.1007/s11027-008-9165-2

McLaughlin A, Mineau P (1995) The impact of agricultural practices on biodiversity. Agric Ecosyst Environ 55(3):201-212. https://doi.org/10.1016/0167-8809(95)00609-V

Moore J (2010) Cheap Food \& bad Money: food, frontiers, and financialization in the rise and demise of neoliberalism. Review (Fernand Braudel Center) 33(2/3):225-261

Mount P, Smithers J (2014) The conventionalization of local food: farm reflections on local, alternative beef marketing groups. $\mathrm{J}$ Agric Food Syst Commun Dev 4(3):101-119

Mundel K (2007) 'Walking through your old way of thinking': the learning dimension of farmers' transitions to sustainable agriculture. Dissertation, University of Toronto

Nardone A, Ronchi B, Lacetera N, Ranieri M, Bernabucci U (2010) Effects of climate changes on animal production and sustainability of livestock systems. 10th world conference on animal production (WCAP) 130 (1?3):57-69. Doi: https://doi.org/10.1016/j.livsci.2010.02.011

National Farmers Union (NFU) (2008) The farm crisis and the cattle sector: toward a new analysis and new solutions, Saskatoon

National Farmers Union (NFU) (2014) Submission to the house of commons standing committee on agriculture and Agri-food regarding: agricultural impacts of the Canada-European Union comprehensive economic and trade agreement, Saskatoon

Nelson J, Stock P (2016) Repeasantisation in the United States. Sociol Rural 58:83-103. https://doi.org/10.1111/soru.12132
Nguyen T, van der Werf $H$, Eugène $M$, Veysset $P$, Devun $J$, Chesneau G, Doreau M (2012) Effects of type of ration and allocation methods on the environmental impacts of beefproduction systems. Livest Sci 145(1?3):239-251. https://doi.org/10.1016/j.livsci.2012.02.010

Organization of Economic Co-operation and Development (OECD) (2017) Agricultural support (indicator). https://data.oecd.org/agrpolicy/agricultural-support.htm. Accessed July 2017

Rogers E (2010) Diffusion of innovations: Simon and Schuster, New York

Savory (2016) http://www.savory.global. Accessed January 5, 2016

Sayre N, Carlisle L, Huntsinger L, Fisher G, Shattuck A (2012) The role of rangelands in diversified farming systems: innovations, obstacles, and opportunities in the USA. Ecol Soc 17(4). https://doi.org/10.5751/ES-04790-170443

Schoenian S (2011) Grazing management. http://wwwsheep101 info/201/grazingsystemshtml Last Modified June 1, 2012, accessed January 1, 2017

Schwartz J (2013) Cows save the planet: and other improbable ways of restoring soil to heal the earth. Chelsea Green Publishing, Hartford

Smith G (2007) Marketing for Added Value. Range Beef Cow Symposium

Srivastava J, Smith N, Forno D (1999) Integrating biodiversity in agricultural intensification: toward sound practices. In environmental and socially sustainable development. The World Bank, Washington, D. C

Statistics Canada (2017a) Alberta has the most beef cattle in Canada and the second largest total farm area, Ottawa

Statistics Canada (2017b) Focus on geography series, 2016 census, Ottawa

Steinfeld H (2006) In: Gerber P, Wassenaar TD, Castel V, Rosales M, de Haan C (eds) Livestock's long shadow: environmental issues and options. Food and agriculture Organization of the United Nations, Rome

Stephenson A (2013) 10 years later: how the mad cow crisis changed an industry and a province. Calgary herald, may 27. h t t p : / / w w w c a $1 \mathrm{~g}$ a $\mathrm{r}$ y h e r a $1 \mathrm{~d}$. $\mathrm{com} /$ business/years+later+crisis+changed+industry+ province+with+videos/8405721/story.html.

Stinner D, Glick I, Stinner B (1992) Forage legumes and cultural sustainability: lessons from history. Agric Ecosyst Environ 40(1):233-248. https://doi.org/10.1016/0167-8809(92 )90095-S

Stock P, Forney J (2014) Farmer autonomy and the farming self. J Rural Stud 36:160-171. https://doi.org/10.1016/j. jrurstud.2014.07.004

Stout W, Fales S, Muller L, Schnabel R, Elwinger G, Weaver S (2000) Assessing the effect of management intensive grazing on water quality in the northeast US. J Soil Water Conserv 55(2):238-243

Stozek T (2008) BSE, farmers and rural communities: impacts and responses across the Canadian prairies. University of Manitoba

Sutherland L, Darnhofer I (2012) Of organic farmers and 'good farmers': changing habitus in rural England. J Rural Stud 28(3):232-240. https://doi.org/10.1016/j. jrurstud.2012.03.003 
Syse KVL (2009) From land use to landscape: a cultural history of conflict and consensus in Argyll : 1945-2005. no. 402, Faculty of Humanities, University of Oslo Unipub, Oslo

Taylor SJ, Bogdan R, DeVault M (2015) Introduction to qualitative research methods: a guidebook and resource. John Wiley \& Sons, Hoboken

Teague R, Provenza F, Kreuter U, Steffens T, Barnes M (2013) Multi-paddock grazing on rangelands: why the perceptual dichotomy between research results and rancher experience? J Environ Manag 128:699-717. https://doi.org/10.1016/j. jenvman.2013.05.064

Van der Ploeg JD, Roep D (2003) Chapter 3: multifunctionality and rural development: the actual situation in Europe. In: van Huylenbroeck G, Durand G (eds) Multifunctional agriculture: a new paradigm for European agriculture and rural development. Ashgate, Aldershot, pp 37-53

Van der Ploeg JD (2000) Revitalizing agriculture: farming economically as starting ground for rural development. Sociol Rural 40(4):497-511. https://doi.org/10.1111/14679523.00163

Van der Ploeg JD (2003) The virtual farmer: past, present and future of the Dutch peasantry: Uitgeverij Van Gorcum

Van der Ploeg JD (2008) The new peasantries: struggles for autonomy and sustainability in an era of empire and globalization: Routledge, London

Van der Ploeg JD (2009) Peasant Agriculture. In: Thrift N (ed) International encyclopedia of human geography. Elsevier, Oxford, pp 108-113

Van der Ploeg JD (2010) The peasantries of the twenty-first century: the commoditisation debate revisited. J Peasant Stud 37(1):130. https://doi.org/10.1080/03066150903498721
Van der Ploeg JD (2014) Peasant-driven agricultural growth and food sovereignty. J Peasant Stud 41(6):999-1030. https://doi. org/10.1080/03066150.2013.876997

Van der Ploeg JD (2015) Peasantry in the twenty-first century. In: Wright J (ed) International encyclopedia of the Social \& Behavioral Sciences. Elsevier, Oxford, pp 664-668

Verified Beef Production Plus (VBP+) (2017) What is VBP+. Canadian Cattlemen's Association. $\mathrm{http}: / /$ verifiedbeefproductionplus.ca/about- vbp/what-is-vbp. cfm. Accessed July 18, 2017

Walker J (1995) Viewpoint: grazing management and research now and in the next millennium. J Range Manag 48(4): 350-357. https://doi.org/10.2307/4002488

Wallace Center at Winrock International (2016) Making Sense of the Many Systems of Rotational Grazing. http://pastureproject.org/pasture-management/rotationalgrazing-systems/. Accessed May 15, 2017

White S, Sheffield R, Washburn S, King L, Green J (2001) Spatial and time distribution of dairy cattle excreta in an intensive pasture system. J Environ Qual 30(6):2180-2187. https://doi. org/10.2134/jeq2001.2180

Wiebe N, Wipf K (2011) Nurturing food sovereignty in Canada. In: Wittman H, Desmarais AA, Wiebe N (eds) Food sovereignty in Canada: Creating just and sustainable food systems. Fernwood Publishing, Winnipeg, MB, pp 1-15

World Wildlife Fund (WWF) (2016) Plowprint annual report: facts $\&$ figures, Bozeman

Publisher's note Springer Nature remains neutral with regard to jurisdictional claims in published maps and institutional affiliations. 